\title{
Highly efficient removal of allyloxycarbonyl (Alloc) function provides a practical orthogonal protective strategy for carbohydrates
}

\author{
Guang Hui Zong ${ }^{\text {a }}$, Shi Qiang Yan ${ }^{\mathrm{a}}$, Xiao Mei Liang ${ }^{\mathrm{a}}$, \\ Jian Jun Zhang ${ }^{\mathrm{a}, *}$, Dao Quan Wang ${ }^{\mathrm{a}}$, Fan Zuo Kong ${ }^{\mathrm{b}}$ \\ ${ }^{a}$ Key Lab of Pesticide Chemistry and Application Technology, Department of Applied Chemistry, \\ China Agricultural University, Beijing 100094, China \\ ${ }^{\mathrm{b}}$ Research Center for Eco-Environmental Sciences, Academia Sinica, Beijing 100085, China
}

Received 2 June 2008

\begin{abstract}
Highly efficient removal of allyloxycarbonyl (Alloc) group was achieved in the presence of $\mathrm{CH}_{3} \mathrm{COONH}_{4}, \mathrm{Pd}\left[\mathrm{P}\left(\mathrm{C}_{6} \mathrm{H}_{5}\right)_{3}\right]_{4}$, and $\mathrm{NaBH}_{4}$ in MeOH-THF, within 5 min in almost quantitative yields ( $>90 \%$, isolated yield) without affecting acetyl, benzoyl, isopropylidene, benzylidene, allyl, benzyl, benzyl carbonate, or azido groups.

(C) 2008 Jian Jun Zhang. Published by Elsevier B.V. on behalf of Chinese Chemical Society. All rights reserved.
\end{abstract}

Keywords: Allyloxycarbonyl group; Orthogonal protective strategy; Carbohydretes

Many of the steps required in carbohydrate synthesis involve protection and deprotection of hydroxyl function; therefore, orthogonal masking groups are of crucial importance in carbohydrate chemistry [1]. Allyloxycarbonyl (Alloc) group has served as protective group in organic chemistry [2], especially for amino protecting in peptide synthesis [3-5], and few papers have described its application in carbohydrate preparation [6,7]. Recently, we have explored the allyloxycarbonyl group in oligosaccharide synthesis, and have successfully finished the preparation of Acinetobacter baumannii $\mathrm{O} 10$ antigen tri- and penta saccharides [8,9]. However, using the known procedures for the deprotection of allyloxycarbonyl group [2], we suffered from the low yields (60-70\%) or the production of side products due to the instability of acyl esters. To overcome the difficulty, a series of detailed experiments were carried out and we found that the allyloxycarbonyl groups could be cleaved within $5 \mathrm{~min}$ in almost quantitative yields under our optimized conditions. We report herewith the very efficient technique using allyloxycarbonyl group as the temporary group, the cleavage of which is achieved readily without affecting other protective groups such as acetyl, benzoyl, isopropylidene, benzylidene, allyl, benzyl, or benzyl carbonate groups, thus providing a practical orthogonal protective strategy in carbohydrate chemistry.

As shown in Scheme 1, our investigation began with the preparation of compound $\mathbf{5}$, a useful building block for the synthesis of rhamno-containing oligosaccharides. The deallyl oxycarbonylation of compound 1 was firstly carried out with $\mathrm{Pd}\left[\mathrm{P}\left(\mathrm{C}_{6} \mathrm{H}_{5}\right)_{3}\right]_{4}$ and $\mathrm{NaBH}_{4}[10]$ in $1: 1 \mathrm{MeOH}-\mathrm{THF}$ but it did not give the required 3, instead, it gave the fully

\footnotetext{
* Corresponding author.

E-mail address: zhangjianjun@cau.edu.cn (J.J. Zhang).
} 


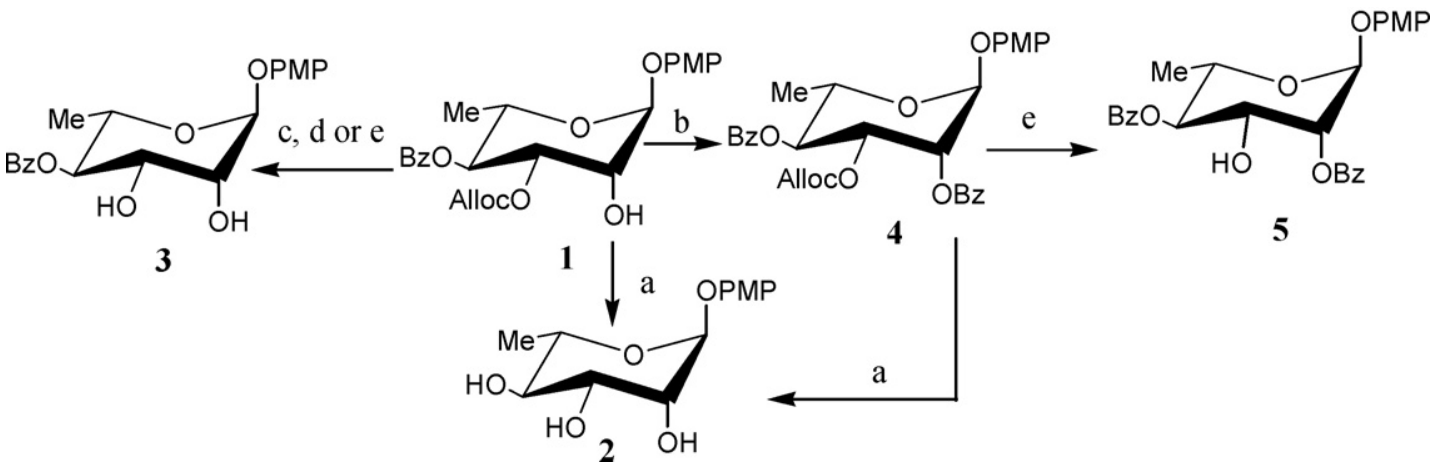

Scheme 1. (a) $\mathrm{Pd}\left[\mathrm{P}\left(\mathrm{C}_{6} \mathrm{H}_{5}\right)_{3}\right]_{4}, \mathrm{NaBH}_{4}, \mathrm{MeOH}-\mathrm{THF}, 0{ }^{\circ} \mathrm{C}, 0.5 \mathrm{~h}, 95 \%$ from 1 to $2 ; 92 \%$ from 4 to 2 ; (b) BzCl-Py. $95 \%$; (c) $\mathrm{Pd}\left[\mathrm{P}\left(\mathrm{C}_{6} \mathrm{H}_{5}\right)_{3}\right]_{4}, \mathrm{P}\left(\mathrm{C}_{6} \mathrm{H}_{5}\right)_{3}$, $\mathrm{Et}_{3} \mathrm{~N}$, THF, rt, $2 \mathrm{~h}, 62 \%$; (d) $\mathrm{Pd}_{2}(\mathrm{dba})_{3}$, and $\mathrm{HCO}_{2} \mathrm{H}, \mathrm{Et}_{3} \mathrm{~N}, 70{ }^{\circ} \mathrm{C}, 40 \mathrm{~min}, 68 \%$; (e) $\mathrm{CH}_{3} \mathrm{COONH}_{4}, \mathrm{Pd}\left[\mathrm{P}\left(\mathrm{C}_{6} \mathrm{H}_{5}\right)_{3}\right]_{4}, \mathrm{NaBH} \mathrm{H}_{4}, \mathrm{MeOH}_{-} \mathrm{THF}, 0{ }^{\circ} \mathrm{C}, 4 \mathrm{~min}$, $97 \%$ from 1 to $3 ; 94 \%$ from $\mathbf{4}$ to $\mathbf{5}$.

deprotected product 2 in excellent yield within $0.5 \mathrm{~h}$ at $0{ }^{\circ} \mathrm{C}$. We rationalized that the concomitant removal of the benzoyl group of $\mathbf{1}$ (also in the case of $\mathbf{4}$ ) was because of the instability of acyl groups under rather strong basic conditions. For the selective removal of Alloc group in 1, we turned our attention to the reported procedure using $\mathrm{Pd}\left[\mathrm{P}\left(\mathrm{C}_{6} \mathrm{H}_{5}\right)_{3}\right]_{4}-\mathrm{P}\left(\mathrm{C}_{6} \mathrm{H}_{5}\right)_{3}-\mathrm{Et}_{3} \mathrm{~N}$ system [5] and compound 3 was obtained in $62 \%$ yield. Besides, we also tried to use $\mathrm{Pd}_{2}(\mathrm{dba})_{3}$ as the catalyst [11] at relatively high temperature $\left(70{ }^{\circ} \mathrm{C}\right)$, yielding $\mathbf{3}$ in $68 \%$ yields.

Table 1

Reaction condition: $\mathrm{CH}_{3} \mathrm{COONH}_{4}$ (10 equiv), $\mathrm{NaBH}_{4}$ (1 equiv), $\mathrm{Pd}\left[\mathrm{P}\left(\mathrm{C}_{6} \mathrm{H}_{5}\right)_{3}\right]_{4}\left(0.05\right.$ equiv), $\mathrm{NaBH}_{4}\left(1\right.$ equiv), MeOH-THF, $0{ }^{\circ} \mathrm{C}, 1-5$ min.

Substrate

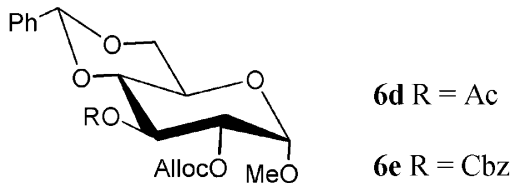

$\underbrace{\mathrm{AllocO}}_{\mathrm{OBz}}$
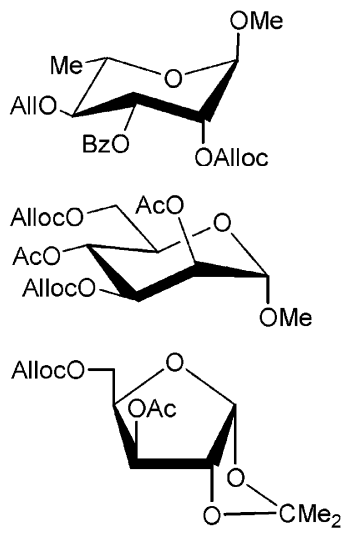

6f

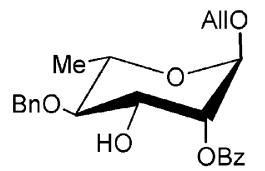

$7 \mathbf{f}(91 \%)$

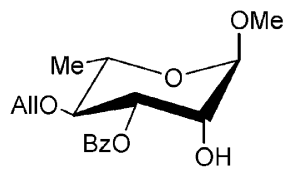

$7 \mathbf{g}(95 \%)$

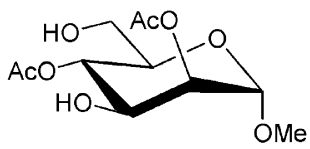

$7 \mathrm{~h}(90 \%)$

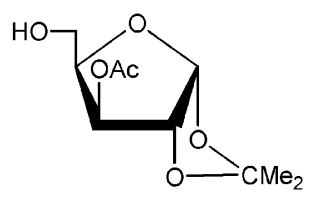




Substrate Product (yield\%)

Obviously, the $\operatorname{Pd}\left[\mathrm{P}_{2}\left(\mathrm{C}_{6} \mathrm{H}_{5}\right)_{3}\right]_{4}-\mathrm{NaBH}_{4}$ system has better reactivity for the removal of Alloc group, but its rather strong basic condition concomitantly destroys the ester linkage. With this in mind, 10 equiv of $\mathrm{CH}_{3} \mathrm{COONH}_{4}$ was added to the reaction mixture for decreasing the basicity of the system. It was found with our great pleasure that the reaction was highly accelerated and the Alloc group was removed within $5 \mathrm{~min}$ (a second portion of $\mathrm{NaBH}_{4}$ was added for assurance the completion of the reaction), keeping benzoyl group untouched, and the product was obtained in almost quantitative yield ( $>94 \%)$ after silica gel chromatography purification.

For disclosure of the application scope of the developed method, differentially protected substrates $\mathbf{6 a}-\mathbf{j}$ was prepared in our group. It was found that selective deallyloxycarbonylation of these carbohydrates proceeded smoothly to afford the required products $\mathbf{7 a}-\mathbf{j}$ in high yields (Table 1) [12]. Of particular interest is the substrate $\mathbf{6} \mathbf{g}$ and $\mathbf{6 j}$; in substrate $\mathbf{6} \mathbf{g}$, two allyloxycarbonyl groups were removed and no $4 \rightarrow 6$ acetyl migration was observed, and in substrate $\mathbf{6 j}$ [8], the azido group in the disaccharide remained stable under the reaction conditions.

In conclusion, a highly efficient experiment procedure was developed for the chemoselectively deprotection of allyloxycarbonyl group in carbohydrates. The high efficiency (reaction time less than $5 \mathrm{~min}$ ), high isolated yields (9097\%), and high selectivity (without affecting a series of protective groups, including isopropylidene, benzylidene, benzyl, allyl, benzoyl, acetyl, benzyloxycarbonyl and azido) of the reaction highlighted the usefulness of the method as a practical orthogonal protecting strategy in carbohydrate synthesis.

\section{Acknowledgments}

This work was supported by Ph.D. Programs Foundation of Ministry of Education of China, No. 20070019072 and the Research Foundation of China Agricultural University No. 90020031.

\section{References}

[1] C.C. Wang, J.C. Lee, S.Y. Luo, S.S. Kulkarni, Y.W. Huang, C.C. Lee, K.L. Chang, S.C. Hung, Nature 446 (2007) 896.

[2] T.W. Greene, P.G.M. Wuts, Protective Groups in Organic Synthesis, 3rd ed., John Wiley \& Sons, Inc., New York, 1999 , p. 183.

[3] H. Kunz, S.F. Bochnitschek, H. Waldmann, C. Unverzagt, Chem. Pept. Proteins 4 (1989) 119.

[4] N. Thieriet, J. Alsina, E. Giralt, F. Guibé, F. Albericio, Tetrahedron Lett. 38 (1997) 7275.

[5] T.S. Zatsepin, D.A. Stetsenko, M.J. Gait, T.S. Oretskaya, Tetrahedron Lett. 46 (2005) 3191.

[6] P. Boullanger, P. Chatelard, G. Descotes, M. Kloosterman, J.H. Van Boom, J. Carbohydr. Chem. 5 (1986) 541.

[7] H. Takeo, Y. Haruo, T. Hirokazu, T. Takashi, J. Carbohydr. Chem. 14 (1995) 165.

[8] J.J. Zhang, S.Q. Yan, X.M. Liang, J.P. Wu, D.Q. Wang, F.Z. Kong, Carbohydr. Res. 342 (2007) 2810.

[9] J.J. Zhang, G.H. Zong, X.M. Liang, Y.Q. Li, D.Q. Wang, F.Z. Kong, Chin. Chem. Lett. 19 (2008) 415.

[10] R.J. Cvetovich, D.H. Kelly, L.M. DiMichele, R.F. Shuman, E.J.J. Grabowski, J. Org. Chem. 59 (1994) 7704.

[11] J.P. Genet, E. Blart, M. Savignac, S. Lemeune, S. Lemaire-Audoire, J.-M. Bernard, Synlett (1993) 680.

[12] Coumpound $\mathbf{6 a - 6 g}$ were prepared in our group and all new compounds were characterized by $300 \mathrm{MHz}$ NMR and MALDI-TOF mass spectrometry. A representative procedure for the deallyloxycarbonylation was as follows: to a cooled $\left(-10^{\circ} \mathrm{C}\right)$ solution of compound $6 \mathbf{a}$ (422 mg, $1 \mathrm{mmol})$ in 1:1 MeOH-THF $(20 \mathrm{~mL})$ in $100 \mathrm{~mL}$ flask was added $\mathrm{CH}_{3} \mathrm{COONH}_{4}(771 \mathrm{mg}, 10 \mathrm{mmol})$. With vigorous stirring, $\mathrm{NaBH}_{4}$ (37 mg, $1 \mathrm{mmol}), \mathrm{Pd}\left[\mathrm{P}\left(\mathrm{C}_{6} \mathrm{H}_{5}\right)_{3}\right]_{4}(57 \mathrm{mg}, 0.05 \mathrm{mmol})$, and second portion of $\mathrm{NaBH}_{4}(37 \mathrm{mg}, 1 \mathrm{mmol})$ were added sequentially and quickly. After the addition of the second portion of $\mathrm{NaBH}_{4}$, the reaction was monitored with TLC at the end of every 1 min until completion. The reaction mixture was concentrated under vacuum, the residue was dissolved in $\mathrm{CH}_{2} \mathrm{Cl}_{2}(50 \mathrm{~mL})$ and washed with brine (10 $\left.\mathrm{mL}\right)$, then the organic phase was dried over $\mathrm{Na}_{2} \mathrm{SO}_{4}$. Evaporation and purification by flash column chromatography (petroleum ether/ethyl acetate 3:1) afforded compound $7 \mathbf{a}$ as a syrupy solid $(328 \mathrm{mg}, 97 \%)$. Compound $7 \mathbf{a}$ : $[\alpha]_{\mathrm{D}}{ }^{25}+34.2\left(c 1.1, \mathrm{CHCl}_{3}\right) ;{ }^{1} \mathrm{H} \mathrm{NMR}\left(\mathrm{CDCl}{ }_{3}, 300 \mathrm{MHz}\right.$, 
$\delta$ ppm): $5.08(\mathrm{dd}, 1 \mathrm{H}, J=1.5,3.0 \mathrm{~Hz}, \mathrm{H}-2), 5.05(\mathrm{dd}, 1 \mathrm{H}, J=9.7 \mathrm{~Hz}, \mathrm{H}-4), 7.62(\mathrm{~d}, 1 \mathrm{H}, J=1.5 \mathrm{~Hz}, \mathrm{H}-1), 4.12(\mathrm{~m}, 1 \mathrm{H}, \mathrm{H}-5), 3.74-3.60(\mathrm{~m}, 3 \mathrm{H}$ H-3, H-6), 2.69 (bs, $1 \mathrm{H}, \mathrm{OH}), 2.46$ (bs, $1 \mathrm{H}, \mathrm{OH}), 2.16,2.14\left(2 \mathrm{~s}, 6 \mathrm{H}, 2 \mathrm{COCH}_{3}\right)$; MALDI-TOF MS Calcd. for $\mathrm{C}_{18} \mathrm{H}_{24} \mathrm{O}_{8}: \mathrm{m} / z$ 368.15. Found: $391.40[\mathrm{M}+\mathrm{Na}]$. Compound $7 \mathrm{~h}:[\alpha]_{\mathrm{D}}{ }^{25}+45.1\left(c 1.1, \mathrm{CHCl}_{3}\right) ;{ }^{1} \mathrm{H} \mathrm{NMR}\left(\mathrm{CDCl}_{3}, 300 \mathrm{MHz}, \delta \mathrm{ppm}\right): 6.97(\mathrm{~m}, 2 \mathrm{H}), 6.80(\mathrm{~m}, 2 \mathrm{H}), 5.38(\mathrm{dd}, 1 \mathrm{H}$ $J=1.0,2.9 \mathrm{~Hz}, \mathrm{H}-2), 5.36(\mathrm{~d}, 1 \mathrm{H}, J=1.0 \mathrm{~Hz}, \mathrm{H}-1), 4.26(\mathrm{~m}, 1 \mathrm{H}, \mathrm{H}-3), 3.97-3.78$ (m, 4H, H-4, H-5, H-6), $3.76(\mathrm{~s}, 3 \mathrm{H}, \mathrm{OCH}$ ), 2.54 (bs, $1 \mathrm{H}$, $\mathrm{OH}), 2.16,2.14\left(\mathrm{~s}, 3 \mathrm{H}, \mathrm{COCH}_{3}\right)$; MALDI-TOF MS Calcd. for $\mathrm{C}_{11} \mathrm{H}_{18} \mathrm{O}_{8}: \mathrm{m} / z$ 278.10. Found: 301.34 [M+Na]. Compound 7i: $[\alpha]_{\mathrm{D}}{ }^{25}+32.3(c$ $\left.1.0, \mathrm{CHCl}_{3}\right) ;{ }^{1} \mathrm{H}$ NMR (DMSO- $\left.d_{6}, 300 \mathrm{MHz}, \delta \mathrm{ppm}\right): 5.85(\mathrm{~d}, 1 \mathrm{H}, J=3.7 \mathrm{~Hz}, \mathrm{H}-1), 5.41(\mathrm{~d}, 1 \mathrm{H}, J=5.0 \mathrm{~Hz}, \mathrm{H}-3), 4.41(\mathrm{~d}, 1 \mathrm{H}, J=3.7 \mathrm{~Hz}, \mathrm{H}-3)$ 4.24-4.01 (m, 4H, H-4, H-5, OH), $2.03\left(\mathrm{~s}, 3 \mathrm{H}, \mathrm{COCH}_{3}\right), 1.37,1.03\left(2 \mathrm{~s}, 6 \mathrm{H}, \mathrm{C}\left(\mathrm{CH}_{3}\right)_{2}\right)$; MALDI-TOF MS Calcd. for $\mathrm{C}_{10} \mathrm{H}_{16} \mathrm{O}_{6}: m / z 232.10$ Found: $255.21[\mathrm{M}+\mathrm{Na}]$. 